\title{
CLIMATE CHANGE AND WATER RESOURCES: A CASE STUDY OF THE CANADIAN PRAIRIE REGION
}

\author{
SURENDRA KULSHRESHTHA \\ University of Saskatchewan, Saskatoon, Canada
}

\begin{abstract}
Climate change through altering the hydrologic regime would affect water supply in various parts of the world. Dry regions of Canada, such as the semi-arid Prairies, would be affected harder under the project climate change scenarios. This chapter reviews water availability and demand for the province of Saskatchewan, located in the semi-arid region of Canada. Implications of climate change for value of water and other socio-economic issues are also identified. In the study region, it is inevitable that climate change would bring forth lower water availability, change in the seasonality of precipitation and its form, higher water demand for agricultural production plus other related implications. The latter type of implications may include health impacts, regional and local conflicts, and interregional migration of people. Under the future water stress levels, it is imperative that integrated water management, including demand management, is undertaken. Although climate change may be a factor that would affect future water resources, equally important are factors such as population, technology, people's attitude about water use and wastage. Keywords: climate change, integrated water management, irrigation, water demand, water supply
\end{abstract}

\section{INTRODUCTION}

Water is an economic good. Its importance for the society cannot be denied as the Dublin Statement on Water has accepted the resolution that 'water has an economic value in all competing uses and should be recognized as an economic good' [1]. There is a general agreement that climate change (through greenhouse warming) will have major impacts on water resources [2]. The Intergovernmental Panel on Climate Change has assessed, with a high confidence, that freshwater systems would be affected mainly by increases in temperatures, sea-level rise and precipitation variability [3]. Accordingly, sensitivity to climate in Canada and the cross-cutting nature of the water issues are important considerations for future water management in semi-arid regions of the Canadian Prairies. Decreased water levels would impact many sectors, including transportation, tourism and recreation, fisheries, industry and energy, municipalities, agriculture and health [4].

Study of climate change impacts on water resources is a complex area. Even more complex is the investigation of the issue of how supply and demand are impacted under climate change and how would the society adapt to these changes. Since water availability as well its demand is specific to a local setting, these issues are many and varied. This chapter illustrates the state of our knowledge in the context of the Canadian Prairie region.

\section{OBJECTIVE OF THE STUDY}

The primary objective of this chapter is to review the state of our knowledge on water resources and climate change, particularly in the context of the semi-arid region of Canadian Prairie Provinces. It begins by providing a glimpse of nature of climate change predicted for the region in Section 3. This is followed by outlining the conceptual interrelationships that could be used in understanding climate change and water resources, first in terms of water availability in Section 4, and then for water demand in Section 5. Section 6 contains a review of various socio-economic issues related to water resources and climate change, followed by implications for policy in Section 7. The last section presents a summary of the chapter. 


\section{GLIMPSE OF CLIMATE CHANGE FOR THE PRAIRIE REGION}

Climate change refers to changes in the climate of the earth due to increased amount of heat-trapping greenhouse gases found in the atmosphere. Much of the literature suggests that climate change can be attributed to natural and anthropogenic forcing agents [5], although the magnitude and direction of expected climate change have been both hard to define. In the context of the Prairie region, major physical impacts in the context of water resources include the following: (i) an increase in the average temperature; (ii) an increase or slight decrease in some regions in precipitation; (iii) change in the intra-seasonal distribution of precipitation and form of precipitation (snow vs. rain) and (iv) increased likelihood of extreme events, such as droughts and floods.

The magnitude of the above changes would vary according to location, although impacts are predicted to be more severe for the higher latitudes, such as the SSRB and northern Prairies. According to Natural Resources Canada [6], temperatures in the Prairie region would increase from 2 to $4.5^{\circ} \mathrm{C}$, with a greater increase in the southern most parts of the prairies. Precipitation in this region would not increase more than 5\% from the 1961-1990 mean (an increase of about 3.75-15 mm from the 1961-1990 mean values of 285-450 mm). Similarly, the frequency of droughts as well flooding in the region would increase, which may affect various economic sectors, particularly dry land agriculture production. This may result in producers demanding more irrigation development, thereby increasing demand for water. Other sectors may also find the need to make adjustments in their water demand under an altered climate regime. Impact of climate change on value of water would be a culmination of impact on water supply (availability) and its demand, further complicated by institutions and their policies.

\section{IMPACT ON WATER AVAILABILITY}

For the Prairie regions of Canada, very few investigations have been undertaken reporting quantitative estimates of water availability. Although these results are presented below, this is a serious gap in our knowledge about impact of climate change on water resources in the Southern part of the Prairie region.

\subsection{Change in temperature and precipitation}

For most of western Canada, including the Prairie Provinces, snowmelt and glacier runoff from mountainous areas are the major sources of water supply. With warmer climate, river flows during summer period are becoming lower and, therefore, greater shortages during the periods of peak demand [7]. However, the magnitude of these changes is uncertain. It is also predicted that extreme hydrologic events such as ice storms, droughts and floods will increase due to climate change [7]. Martz et al. [8] reported a reduction in water availability in the South Saskatchewan River Basin by 2046 of 546 million cubic meters, relative to 1996 level. Another study [9] estimated stream flow in Alberta to decrease from 12\% to 56\% of the current flow under different climate change scenarios.

\subsection{Impact of extreme events}

Canadian prairies have been the most susceptible region to droughts in Canada due to high variability of precipitation in time and space caused by disruptions to an expected precipitation pattern and can be intensified by an exceptionally high temperature that increase evapotranspiration. High surface temperatures could intensify drought conditions through 
enhanced evaporation in summer and increased sublimation and melting of the snowpack in winter. The Intergovernmental Panel on Climate Change [10] has concluded that climate change has begun to affect the frequency, intensity and duration of extreme events such as extreme temperatures, extreme precipitation, droughts, etc. For Southern Prairies, an analysis of projected changes to precipitation and drought characteristics between the1971-2000 and 2041-2070 periods suggests a decrease in mean precipitation in summer and an increase for the other seasons, whereas the severity, frequency and maximum duration of both short- and long-term droughts are projected to increase, with the largest projected changes associated with longer drought events [11].

\subsection{Impact on water quality}

Change in precipitation and water availability would likely have a negative impact on water quality [7]. Besides lower summer flows, lower quality water is expected with higher suspended solids from more frequent severe storms and potential re-growth of bacteria resulting from higher water temperatures. Lower water availability may also result in deterioration of water quality through eutrophication - development of summer algae on lakes [7]. In lakes, climate change will affect the quality of water through three mechanisms: changes in throughput and volume, higher water temperature and reduction in ice cover. The change in temperature will affect the rate of bacteriological activity and the amount of oxygen to support it.

\subsection{Impact on groundwater and other water bodies}

A decline in the stream flow and the change in the intra-seasonal distribution of precipitation along with the impact on evapotranspiration may, in southern prairies, drain groundwater levels, water storage as glaciers, snowcaps as well as negatively impact wetlands [12]. A caveat though is that our ability to measure the potential impacts of climate change and variability on groundwater is limited due to the following reasons: (i) the magnitude and timing of the impact of climate variability and change on aquifers (reflected in water levels) are difficult to recognize and quantify due to the difference in time frame between climate variations and the aquifer's response to them and (ii) different types of aquifers respond in different ways; shallow aquifers are more responsive to stresses imposed at the ground surface compared with deep aquifers. These aquifers are affected by local climate changes and deep aquifers by regional climate changes. Shallow aquifers will also be more impacted by climate variability, since deep aquifers have an increased capacity to buffer the effects of climate variability.

The impact of climate change on surface and ground water would also lead to other changes on the prairies. These may include: (i) wetlands, supported by and interact strongly with groundwater in some areas; (ii) stream flow is sustained by groundwater when contributions from direct precipitation (base flow) are lacking; (iii) influent rivers, which contribute to recharge of aquifers and (iv) springs, which are groundwater discharge features [13]. Many of these water bodies are responsible for ecosystem services, which would be reduced or totally lost under climate change.

\subsection{Soil moisture shortage}

Associated with changing patterns of precipitation and higher temperature would be reduced soil moisture levels. Moisture deficits for the southern part of the Prairie Provinces would 
increase, in some cases by $490 \mathrm{~mm}$ [14]. The area with high level of aridity would increase and would cause a devastating impact on crop production. Another impact of climate change is through modification of form of precipitation. In the southern part of the Prairies, much of the winter moisture is in the form of snow, which melts before seeding of crops. However, under climate change more of the winter precipitation would be in the form of rain. This moisture would be added to the stream flow and not available as soil moisture for crops.

In summary, prospects for water availability for the southern portion of the Prairies region suggest reduced amount of water. This would be a result of retreating glaciers plus reduced or highly variable precipitation. The hydrologic effects of climate change discussed above will put stresses on the amount of water available for withdrawal uses, especially in already dry areas of the region. Pockets of water stress are likely to appear in the future, depending on water demand levels relative to supply.

\section{IMPACT ON WATER DEMAND}

Studies of climate change impacts on water demand, or response of water users to changes in runoff, are relatively few, particularly for the Canadian Prairies. Reduced water availability has consequences for municipal water supply, navigation, hydroelectric power, recreation and ecosystem health [7]. Impact of climate change on water demand may be induced through both international sources as well as local (regional and national) situation. International forces would affect demand for export products, where increased exports would require more water to produce them. Although production is determined locally by weather conditions, international markets determine market prices for many of the Canadian products, which may induce/reduce production levels and indirectly affect water demand levels. In this section, the effect of climate change on water demand is discussed, both conceptually and in terms of empirical results, where available.

\subsection{Domestic water demand levels}

The change of climate will be reflected directly in the change of domestic water requirement and indirectly by socio-economic changes induced by climate change. The climatic influence on water demand is reflected in seasonal variations in the level of water demand as well as in terms of reaction of the customers to longer term changes in weather and through that on the factors affecting water demand. In a cross-sectional study [15] of water demand patterns, regional climate was found to be an important determinant of water demand levels. It has been shown that $1 \%$ increase in the net evapotranspiration during the sample period would increase water demand by $0.406 \%$ [15]. This would suggest that under a warmer climate, water demand for residential purposes would increase significantly.

The effect of short-term variability in climate on water has also been studied [15-17]. Droughts have a significant impact on water demand [16]; for every $1 \%$ increase in the net evaporation, the residential water demand per capita per year in the region increases by $0.43 \%$, which suggests that for every $1 \%$ increase, the residential water demand increases by about half a percent. More recently, assuming climate change to have a significant impact, residential water use in Saskatchewan was estimated to increase by 24\% in 2060 [17]. Increased frequency of droughts in the region would also affect the water use level for domestic purposes.

\subsection{Industrial and power generation water demand}

The water demand in industry provides cooling water for thermal power stations, besides being used in the processing of food products, and for non-agricultural industrial demand. 
The industrial water demand varies considerably with the type of industry. Relatively speaking, primary metal, pulp and paper and agricultural processing industries (such as the slaughtering and meat processing operations) require more water to produce a similar value of the final product.

Water demand by industries may be affected by climate change in several ways: direct and indirect impacts. In terms of direct impact, climate change would increase the water requirements for cooling in manufacturing and thermal power generation, although its magnitude would vary from region to region. Mining water use could be an exception to this since much of the water is used in processes that are not affected by climate. In addition, two indirect effects of climate change may also be created: First, climate change may alter the demand for some products. This type of change would alter the product mix produced in the region and change the water demand for industrial purposes. Second, a change in the demand for certain goods due to climate change may alter the power requirements for the region, which may then affect the water demand levels.

The indirect effects of climate change through its effect on energy may be just as important as the direct effects (activities such as irrigation, grain drying, seeding and harvesting are examples of climate-dependent agricultural activities that have high energy uses).

One of the major impacts of climate change is expected to be on hydropower production. Reduced stream flows in the Prairie region from higher evapotranspiration and higher frequency of droughts would reduce power generation capacity. Loss of base stream flow is especially important during dry summers when the demand for electricity is high. Decreased base flow contribution and changes in timing may result in substitution of hydro-power by other types of power generation. This may lead to more greenhouse emissions and may further contribute to global warming.

\subsection{Agricultural water demand}

Among various uses of water, agricultural water demand is the largest source. For example, in 2010, Saskatchewan used a total of 930 thousand $\mathrm{dam}^{3}$ (one dam ${ }^{3}$ is equivalent to one million litres or 0.8107 acre-feet of water), of which agriculture used 610 thousand dam $^{3}$ (or $65.5 \%$ of total) [17]. Total agricultural water demand can be broken into five major uses, as shown in Table 1. Irrigation is the major water demand in Saskatchewan, constituting 93\% of the total. Other water uses are relatively smaller.

Estimation of agricultural water under climate change is a complex subject on account of three types of impacts that may occur, some of them, simultaneously: (i) direct effect of the changed climate on the water requirements; (ii) indirectly induced effect of climate change

Table 1: Distribution of total agricultural water demand in Saskatchewan, by type, 2010.

\begin{tabular}{lll}
\hline Water demand type & Amount in dam $^{3}$ & Percent of total \\
\hline Irrigation & 609,972 & 93.0 \\
Livestock & 43,591 & 6.6 \\
Pesticide application & 1,492 & 0.2 \\
Greenhouses and nurseries & 559 & 0.1 \\
Aquaculture & 447 & 0.1 \\
Total & 656,062 & 100.0 \\
\hline
\end{tabular}




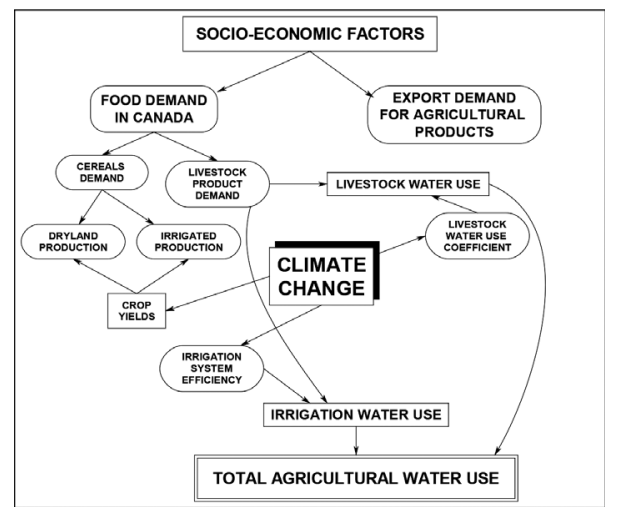

Figure 1: Agricultural water demand under climate change.

and (iii) policy-induced effects of the climate change. Each of these impacts is conceptualized in Fig. 1.

\subsubsection{Direct impact of climate change on water requirements}

The direct effect of climate change on the agricultural water demand can be seen in terms of two major interrelationships: (i) change in the irrigation production function and (ii) change in the water requirements for stockwatering. The first effect would basically be a biological one. It is possible that under a warmer climate, coupled with a higher occurrence of droughts in a region, more water would be required to produce the same quantity of crops. In a similar vein, under a warming earth, livestock may also require more water to sustain them. Both of these may increase the total agricultural water requirements.

\subsubsection{Indirect effect of climate change on agricultural water demand}

The indirectly induced effects of climate change would be realized through a number of changes that will be produced by the climate change. These include:(i) reduced efficiency of water delivery system; (ii) effect on the dryland (rain fed or non-irrigated) food production; (iii) effect on demand for food and its composition and (iv) change in the livestock production function, particularly with respect to feed grains consumption. All of these changes may suggest the need for more irrigation in the future.

\subsubsection{Policy-induced impacts of climate change on agricultural water demand}

The policy-induced impacts under climate change are even more complex since these decisions tend to be lumpy and are not easily predictable. The motivation for more irrigation will result in a need for expansion of irrigation infrastructure by public agencies. Dryland farmers may also see the need for irrigation under more frequent drought conditions, since irrigation is a major adaption under climate change [18].

The effect of climate change on dryland agriculture should be viewed together with other changes that may happen at the same time. Temperature increase may be associated with extending the range of some pests, which are currently being limited by cooler temperatures. In addition, there may be more occurrences of livestock diseases. This may translate into, under warmer climate at mid-latitudes, an increase in the overwintering range and population density of some agricultural pests, while in cool temperate regions there will be more insect 
pests and diseases, which are not present currently. These events would lead to decreased crop yields in some regions, as well as in a lowering of profitability from livestock operations.

In Saskatchewan, the effect of climate change on selected agricultural water demands is summarized in Table 2. The current (2010 level) water demand for irrigation in Saskatchewan would increase by one-and-a-half times this level by 2060 . Climate change would bring forth an increase of $25 \%$ in terms of water requirements for the crops.

\subsection{Recreation, navigation and ecosystem water demand}

The water-related recreation represents an important function in the modern society, particularly in the semi-arid climates. Its importance will grow with the increase in leisure time, and through the need to satisfy basic functions of human life, i.e. rest, entertainment, personal development, etc. Various types of water-related recreation and sports will be, in some way, influenced by the climate change. The increasing temperature will increase the number of days suitable for activities such as bathing and swimming, boating and sailing, among others. In many communities, particularly those without any natural water-adjacent recreation areas, a need for large recreational facilities may be overwhelming, which would lead to higher water demand at the municipal level.

\section{INDUCED IMPACTS OF CHANGE IN WATER AVAILABILITY/DEMAND}

The above discussion has indicated that climate change would affect both water availability and water demand. This may lead to many other repercussions on the socio-economic fabric of the region. Some of these are described in this section.

\subsection{Impact of climate change on value of water}

As the supply of water dwindles and its demand increased, the perception of value of water may undergo major shifts. Under these conditions, the value of water will be determined by the water scarcity in a local or regional setting. Figure 2 shows that all climate-induced physical changes would affect water supply and demand. Valuation of water could be modified by a number of related factors. First and foremost is the policy on charging for water. Property rights on water use licenses would also play an important part in setting the price of water. On

Table 2: Estimated major agricultural water demand for Saskatchewan under climate change, 2010-2060.

\begin{tabular}{lllll}
\hline $\begin{array}{l}\text { Type of agricultural } \\
\text { water demand }\end{array}$ & $\begin{array}{l}\text { Baseline 2010 } \\
\text { level }\left(10^{3}\right. \\
\left.\mathrm{dam}^{3}\right)\end{array}$ & $\begin{array}{l}\text { Change in demand } \\
\text { due to expansion } \\
\text { in 2060 }\left(10^{3} \mathrm{dam}^{3}\right)\end{array}$ & $\begin{array}{l}\text { Effect of climate } \\
\text { change in 2060 } \\
\left(10^{3} \mathrm{dam}^{3}\right)\end{array}$ & $\begin{array}{l}\text { Total water } \\
\text { demand }\left(10^{3}\right. \\
\left.\mathrm{dam}^{3}\right)\end{array}$ \\
\hline $\begin{array}{l}\text { Irrigation } \\
\text { Livestock }\end{array}$ & 610.0 & 671.3 & 320.7 & $1,602.0$ \\
Sub-total & 43.6 & 6.5 & 3.5 & 53.9 \\
Change in water demand due to climate change & 324.2 & $1,655.9$ \\
Irrigation & 653.6 & 677.8 & $25.0 \%$ & $162.6 \%$ \\
Livestock & & $7.5 \%$ & $23.6 \%$ \\
\hline
\end{tabular}

Source: Kulshreshtha et al. [17] 


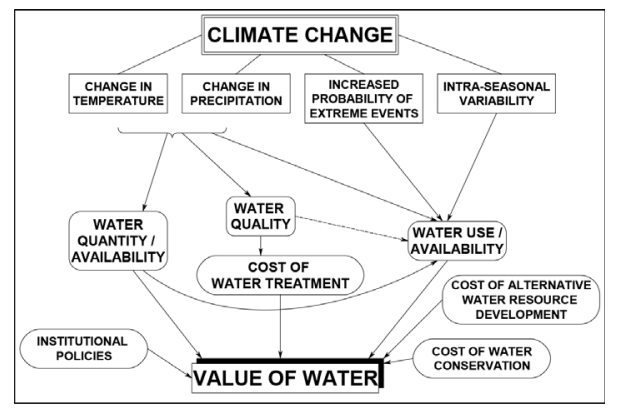

Figure 2: Interrelationships among climate change attributes and value of water.

the demand side, the cost of re-use and water conservation would be the major factors determining the value of water. On the availability side, the cost of developing new water sources (to replace and/or supplement those affected under the climate change) would be a major consideration in valuing water. These issues are discussed further.

\subsubsection{Cost of water development}

The value of water will certainly be determined by the cost of developing new water sources when existing supplies dwindle. These costs are very site-specific. In relatively lower value uses, such as stockwatering, irrigation and hydropower generation, the cost of water may be an important determinant of its demand, unless policies are designed in a manner that the users do not pay the full-cost of the new development. The cost of water development would increase almost exponentially as the scarcity index for water in a given region increases [19].

\subsubsection{Cost of water conservation}

Another way to alleviate water stress in a given region is through water conservation. Opportunities for such conservation are very industry-specific and subject to social views on water conservation. For example, in irrigation, scheduling to deliver water when the plants can use it most effectively and/or switching to crops and varieties that require less water or provide higher returns per unit of water are such alternatives. Adoption of alternative technology in reducing water application rates (such as drip irrigation) is also an effective water conservation measures. Opportunities for curtailing consumptive use of irrigation water through conservation measures are small. In Saskatchewan, water conservation can reduce irrigation water demand by $14.7 \%$ of the projected water demand [17].

In power generation, dry tower cooling virtually eliminates both withdrawal and consumptive water uses in the production of thermoelectric power. But this system is about twice as expensive as wet tower cooling and it results in a loss of thermal efficiency. The costs and opportunities for conserving domestic, industrial and commercial water in the climate change scenarios depend on how much the region has already invested in conservation.

In summary, studies estimating the impact of climate change on value of water are rare. Those that have attempted to deal with values of water resources under climate change $[20,21]$ are according to Hurd et al. [22] 'divorced from that of economic response', and are mere 'back of the envelop estimates'. One needs to develop models that take into account water demand, supply and society's response to adaptation to the climate regime in an integrated manner. 


\subsection{Increased competition for water and interregional conflicts}

Climate change will worsen the competition for water in various regions, particularly those in the semi-arid climates. Competition for freshwater between cities and rural areas is intensifying in many parts of Saskatchewan. The end result of these changes will be more disputes among water users within the same region. In some regions, there may arise a need for inter-regional transfers of water, which would demand a special handling in the wake of uncertainty created by the climate change and contentious nature of such transfers.

Global climate change appears to be the most likely change that would affect international politics because of its wide scope and management [21]. However, such conflict may also arise within a basin. Situation will be worse for regions (such as Alberta and Saskatchewan) that share water resources, such as the lakes and rivers, and for those where a large part of the water supply is obtained through flow from other regions. As water stress in some parts of the semi-arid regions increases, migration of people to less drier regions may also commence.

\subsection{Socio-economic impacts}

The various degrees of vulnerability of various countries to climate change would have significant social-economic-political implications on the countries. Climate change would affect all sectors of the society. Some of these changes would be as a direct result of climate change, while others would be through economic linkages. Extreme events, such as the drought or floods, would decrease the economic profitability of production in all sectors, but more so for the agricultural production. This may eventually affect the competitive position of one region to other, and may lead to inter-regional shifts in economic activity, followed by massive migration of people. The adjustments in regional pattern for agriculture in many countries could be triggered by the climate change and the agricultural and economic prospects at the farm, regional or state level can be affected. An increase in the drought frequency could have a devastating effect on the water resources in the region, as reported by Wheaton et al. [23]. In assessing the potential impact of future climate changes on human activities, the fundamental subject of concern is the adaptive capacity of social and economic systems. Society in the past has adapted to similar changes, but more severe droughts may tax this adaptive capacity to the utmost.

\subsection{Health impacts}

Water resources are involved directly or indirectly, according to the World Health Organization [24], in $80 \%$ of all diseases. Both surface and groundwater receive large amounts of industrial waste, which can cause health hazards, namely cancer or cardiovascular diseases. On the other hand, water contributes in many aspects to our good health by its recreational and environmental value. Mineral waters are used to treat rheumatic and digestive problems, and for bathing and drinking. All these health aspects may be influenced by the future climatic changes.

The developing countries may be affected by the climatic change catastrophically. Many regions are not served by the public water supply, and diseases caused by the pollution of drinking water are the most important aspect of water-related diseases. The climatic changes can even worsen this situation by an increase in pollution, by reduction of the water resources for drinking purposes and by reduction of the scarce capital that can be allocated to development of 
water resources systems with drinking water supply objective. In 1980, around 25,000 people died every day because of lack of clean drinking water [25]. The warmer temperature will increase the drinking water requirements, and unless the quantity and quality of drinking water is enhanced, the water-related diseases will increase in number and seriousness.

\section{IMPLICATIONS FOR POLICY MAKERS}

Adaptation to climate change, and in particular to extreme events, would require policy action on several fronts. They are needed in order to minimize the impact of climate change on people, socio-economic fabric of the nation and ecosystems.

\subsection{Development of low-regrets measures}

A good starting point for policy makers is to identify low-regret measures for water management in order to reduce the impact of future climate change. Field et al. [26] have suggested measures, such as improving water use efficiency, enhancing water storage, implement integrated water management (as discussed in Section 7.2), effective surveillance, prediction and warning of extreme events, and adequate funding of water infrastructure, among others.

\subsection{Need for changes in legal and institutional development}

Climate change would require changes in legal and administrative framework, both nationally as well as regionally. There would emerge, under climate change, a need in various regions to develop a clear and concise water management policy, and appropriate legal structures. Climate change may also bring about a major challenge for human resources development. To implement the new mandate of water management, training of water managers, researchers and policy makers would be required. Strengthening of the training programme to meet the need of many developing countries will be a mammoth effort.

\subsection{Integrated water management}

The attitude of water management planners should be such so as to be aware of the forthcoming challenge posed by the climate change, and to project and plan water resources in an appropriate manner. Such planning should be adaptable, robust and resilient to withstand the possible future changes of climate. As demand for dependable water supplies increases and its supplies dwindle, the type of water resources development that would be needed under climate change will be different. Simple withdrawal of water from streams or rivers would be replaced by provision of water reservoirs to smooth out the irregularity in stream flow on one side, and inter-year variability in its demand on the other. Measures will also have to be developed for proper management of groundwater resources. Williams [27] suggests that possible water management responses under climate change may also include reallocation of water supply from less valuable irrigated agriculture to municipal uses, changes in agricultural methods, increasing incentives for integrated flood management, increasing incentives for watershed management, integrating ecosystem needs in water resources planning and the need to redesigning the operation of the existing water projects.

Under climate change, water scarcity is further exacerbated by decreased quality of water, which may trigger an increased need for water treatment. Under these conditions, water quality management may have to be given a top priority in water policy making. It may be cheaper to solve the problem before it happens than to wait until it has major impacts on the society. 


\subsection{Demand management}

Under climate change, with limited opportunities for increasing water supply, the only choice for many regions (nations) would be to curtail demand. This would require a carefully constructed demand management system, which can improve the efficiency of water demand on one side and reduce the need for massive investments in water supply infrastructure without bringing undue hardship on the users. The nature of this plan cannot be generic, since measures need to be evaluated on their own merits for a given situation.

Water demand management is based on the premise that the behaviour of the individual can be modified. Economic incentives or penalties can be provided to induce the desired behaviour. Among various economic instruments, the use of tariffs (price) for curtailing water demand is the predominant one. Tariffs can also be devised on a seasonal basis to induce more water conservation during certain times of a year. However, before these tariffs can be effective, measurement of use of water is a very important prerequisite. However, one should note that economic instruments are not the only means by which individuals' behaviours can be modified/changed. Through communications with the users, one may also be able to persuade the users to alter their water demand levels.

Under the looming fear of global warming, demand management measures would have to be devised to ensure: (i) balancing the water demand with water availability; (ii) maintenance of acceptable quality of water; (iii) management of water demand during periods of drought; (iv) matching seasonal water availability with demand and (v) management of inter-year variability in supply through adjustments in water demand levels. Each of these may require different strategies, and therefore, should be considered on a site-specific basis.

With dwindling water supplies, and an increased competition for its use, management of direct water demand may not be sufficient. These measures may need to be supplemented by the management of indirect water demand. One such relatively larger water user is electric power generation. Some of this wasted energy can be reduced by measures that increase the efficiency of this demand through heat recovery and better insulation of houses. As the climatic change may increase the temperature, the summer cooling requirements may also grow. In the future, alternative means, such as the use of industrial waste heat, combination of generation of power and heat, and thermally driven heat pumps, may be explored.

\section{SUMMARY AND CONCLUSIONS}

Canada has a relatively abundant supply of water but its distribution is such that most of this water is in regions with limited/low use. In the southern part of the Prairie Provinces, water availability is relatively lower but its use is higher. Here, major population masses reside and most of the economic activity takes place.

Under climate change, with increased temperature and highly variable precipitation, coupled with higher frequency of droughts, water resources in the region would come under pressure. Climate variables would affect the hydrological cycle, which would affect runoff and evaporation as well as the amount of water in glaciers, snow packs, lakes, wetlands, soil moisture and groundwater. This would reduce the water availability, which would have implications for water demand. Major industries that would require more water under climate change include agriculture (irrigation and livestock), hydro-electric and thermal electric power generation, and ecosystems. If these demands are not met, this would lead to losses in agriculture production and change in land use, and eventually would result in losses in farm and non-farm incomes. 
Although numerous studies of climate change have been directed to Canada, those for the southern portion of the Prairie Provinces (and especially for Saskatchewan) are few and lack empirical estimates of future available water supply. However, it is reasonable to generalize that for this region, climate change would likely result in decreased summer flows, higher summer water temperatures and higher winter flows. Portions of this region that are already under water stress would be affected even worse than others.

Climate change affects not only surface water but also groundwater. In Saskatchewan, rural communities depend on groundwater. However, in spite of its importance, very little is known in terms of impact of climate change on groundwater water dynamics. The shallow unconfined aquifers would be impacted most significantly under climate change.

Changes in water quality and water quantity are inextricably linked. Lower water level tends to lead to higher pollutant concentrations. Higher air temperatures may result in increased surface-water temperatures and decreased duration of ice cover. This may reduce the concentration of dissolved oxygen, as well as higher concentration of nutrients, such as phosphorous. As these concentration levels rise, eutrophication of lakes may result.

Water demand would also be affected by climate change. Warmer temperatures and drier conditions due to climate change would increase water demand in semi-arid regions of the Prairie Provinces. Agricultural, power generation and domestic water users would be affected the most. Outdoor domestic water uses (gardening and lawn watering) and drinking water demand tend to increase under drier conditions. Under a drier climate, farmers may convert their dryland production to irrigation, particularly as an adaptation measure in response to droughts. Thermal electric power generation would be affected both through the direct impact of climate change (through increased water requirements for cooling) as well as through higher induced demand for power by economic sectors and residents.

Some of the adverse impacts of climate change on water resources could be reduced through adaptation. Commonly recommended adaptation to climate change include: water conservation measures, improved water management through planning and preparedness for droughts and other water related adversities; improved allocation of water that is more equitable. Demand management through the use of economic instruments (such as water pricing) has also been proposed as a measure to reduce water demand. While the prospect of climate change adds more uncertainty to water management, climate is only one of many factors influencing future supply and demand for water in a region. Population, social and political factors, economic make-up of the region, technology and the value the society places on alternative water uses may be equally important for future water availability and demand.

\section{REFERENCES}

[1] The Dublin Statement on Water and Sustainable Development, Dublin, Ireland, January 31, available at www.inprim.org/files/Documents/DublinStatmt.pdf, 1992.

[2] International Conference on Water and the Environment, Development Issues for the 21st Century, World Meteorological Organization: Geneva, 1992.

[3] Kundzewicz, Z. \& Maria, L. (Coordinating Lead Authors), Freshwater resources and their management, Climate Change 2007: Impacts, Adaptation and Vulnerability, eds. M. Parry, O. Canziani, J. Palutikof, P. van der Linden, C. Hanson, Cambridge University Press: Cambridge, pp. 173-210, 2007.

[4] Lemmen, D.S. \& Warren, F. (eds.), Climate Change Impacts and Adaptation: A Canadian Perspective, Natural Resources Canada: Ottawa, 2004. 
[5] Albritton, D.L. \& Filho, L.G.M. (\& 19 other lead authors). Technical summary. Climate Change 2001: The Scientific Basis. Contribution of Working Group I to the Third Assessment Report of the Intergovernmental Panel on Climate Change, eds. J.T. Houghton, Y. Ding, D.J. Griggs, M. Noguer, P.J. van der Linden, X. Dai, K. Maskell \& C.A. Johnson, United Kingdom and New York, Cambridge University Press: Cambridge, 2001.

[6] Natural Resources Canada, Climate Change Impacts and Adaptation: A Canadian Perspective, Ottawa, Ontario, 2002.

[7] Frederick, K.D. \& Major, D.C., Climate change and water resources, Climatic Changes, 37, pp. 7-23, 1997. doi: http://dx.doi.org/10.1023/A:1005336924908

[8] Martz, L., Bruneau, J. \& Rolfe, T. (eds.). Climate Change and Water in the South Saskatchewan River Basin. South Saskatchewan River Basin Project Technical Report, University of Saskatchewan: Saskatoon, 2004.

[9] Byrne, J.M., Barendregt, R. \& Schaffer, D., Assessing potential climate change impacts on water supply and demand in Southern Alberta. Canadian Water Resources Journal, 14(4), pp. 5-15, 1989. doi: http://dx.doi.org/10.4296/cwrj1404005

[10] Seneviratne S., Easterling, D., Goodess, C., Kanae, S., Kossin, J., Luo, Y., Marengo, J., McGinnis, K., Rahimi, M., Reichstein, M., Sorteberg, A., Carolina, V. \& Zhang, X., Changes in climate extremes and their impacts on the natural physicalenvironment, eds. C. Field, V. Barros, T. Stocker, Q. Dahe, D. Dokken, K. Ebi, M. Mastraandrea, K. Mach, G. Plattner, S. Allen, M. Tignor \& P. Midgley, Managing the Risks of Extreme Events and Disasters to Advance Climate Change Adaptation, A Special Report of Working Groups I and II of the Intergovernmental Panel on Climate Change, Cambridge University Press: Cambridge, pp. 109-230, 2012.

[11] Pai Mazumder, D., Sushama, L., Laprise, R., Khaliq, R.N. \& Sauchyn, D., Canadian RCM projected changes to short- and long-term drought characteristics over the Canadian Prairies, International Journal of Climatology, 33(6), pp. 1409-1423, 2012. DOI: 10.1002/joc.3521. doi: http://dx.doi.org/10.1002/joc.3521

[12] Climate Change and Water in Alberta; Alberta Government, available at http://www3. gov.ab.ca/env/water/GWSW/quantity/learn/Influence/IF3_climchange.cfm, 2004.

[13] Environment Canada, Threats to Water Availability in Canada, National Water Resource Institute: Burlington, Ontario, 2004.

[14] Nyirfa, W. \& Harron, B., Assessment of Climate Change on the Agricultural Resources of the Canadian Prairies, Prairie Adaptation Research Collaborative: Regina, 2004.

[15] Brockman, J.L., Kulshreshtha, S.N. \& O'Grady, K.L., Municipal Water Use. Saskatchewan Water Corporation: Moose Jaw, Saskatchewan, 1987.

[16] Kulshreshtha, S.N. \& Spriggs, J.D., Water Use in Saskatchewan: Present and Future Levels, Saskatchewan Drought Study Element No. 11, Prairie Farm Rehabilitation Administration: Regina, 1982.

[17] Kulshreshtha, S.N., Bogdan, A. \& Nagy, C., Present and Future Water Demand in Saskatchewan - A Summary by River Basins, Saskatchewan Watershed Authority: Moose Jaw, 2012.

[18] Sauchyn, D. \& Kulshreshtha, S. Prairies, From Impacts to Adaptation: Canada in a Changing Climate, eds. D.S. Lemmen, F.J. Warren, J. Lacroix, E. Bush, Government of Canada: Ottawa, ON, 448 p, 2008. 
[19] Frederick, K.D. \& Schwarz, G.E., Socioeconomic impacts of climate change on US water supplies. Journal of the American Water Resources Association, 35(6), pp. 15631581, 1999. doi: http://dx.doi.org/10.1111/j.1752-1688.1999.tb04238.x

[20] Cline, W.R., The Economics of Global Warming, Institute for International Economics: Washington, DC, 1992.

[21] Titus, J.G., The costs of climate change to the United States, Global Climate Change: Implications, Challenges and Mitigation Measures, eds. S.K. Majumdar, B. Kalkstein, L.S. Yarnal, E.W. Miller, L.M. Rosenfield, Pennsylvania Academy of Science: Philadelphia, PA, 1992.

[22] Hurd, B., Callaway, M., Smith, J.B., \& Krishen, P., The impact of climate change on the US economy, Economic Effects of Climate Change on US Water Resources, eds. R. Mendelsohn, J.E. Neumann, Cambridge University Press: Cambridge, pp. 133-177, 1988.

[23] Wheaton, E., Wittrock, V., Kulshreshtha, S., Koshida, G., Grant, C., Chipanski, A., Bonsal, B., Adkins, P., Bell, G., Brown, G., Howard, A. \& MacGregor, R., Lessons Learned from the Canadian Drought Years 2001 and 2002: Synthesis Report. Agriculture and Agri-Food Canada: Saskatoon, 2005.

[24] World Health Organization, Malaria control - a recognized strategy, WHO Chronicle, 32(6), pp. 226-230, 1978.

[25] Gleick, P.H., Climate change and international politics: problems facing developing countries, Ambio., 18(6), pp. 333-339, 1989.

[26] Field, C.B., Barros, V., Stocker, T. \& Dahe, Q. (eds.), Managing the Risks of Extreme Events and Disasters to Advance Climate Change Adaptation. Special Report of the Intergovernmental Panel on Climate Change. Cambridge University Press: Cambridge, NY, 2012. doi: http://dx.doi.org/10.1017/CBO9781139177245

[27] Williams, P., Adapting water resources management to global climate change. Climatic Change, 15, pp. 83-93, 1989. doi: http://dx.doi.org/10.1007/BF00138847 